\title{
Pengaruh Perbedaan Transportasi Sistem M-CLOVE dengan Konvensional dan Jenis Kelamin terhadap Respon Fisiologis Ayam Broiler
}

\author{
The Influence of M-CLOVE and Conventional Transportation with Sex Againts the Broiler \\ Physiological Response
}

\author{
T. A. I. P. Pratama1), A. Yani' ${ }^{2)}$, R. Afnan ${ }^{2}$ \\ ${ }^{1}$ Fakultas Peternakan, InstitutPertanian Bogor \\ ${ }^{2}$ Departemen Ilmu Produksidan Teknologi Peternakan, Fakultas Peternakan, Institut Pertanian Bogor, Jl. \\ Agatis, Kampus IPB Dramaga, Bogor 16680, Indonesia
}

\begin{abstract}
Meat consumption in Indonesia has increased with most needs come from broiler meat. However, it is not followed by development of the transportation technology that consider animal welfare. The purpose of this study was to compare the level of broiler stress measured from comb, shank and rectal temperature among sex between conventional transport system and environmentally transportation M- CLOVE. The results showed average of temperature and relative humidity during the transport process in the M-CLOVE was lower compared to the open crate. Temperature differences occured $1.4{ }^{\circ} \mathrm{C}$ with a relative humidity of $2.5 \%$ different. M-CLOVE transport reduced the level of stress of broiler which was indicated from lower comb temperature, shank temperature and rectal temperature which compared to broiler transported in open crate. Closed system and constant air circulation in the M-CLOVE might reduce the effects of heat generated from exposure to direct sunlight during the transportation process.
\end{abstract}

Keywords: broiler, M-CLOVE, physiological response, transportation

\section{PENDAHULUAN}

Peternakan merupakan subsektor pertanian yang menjadi salah satu pemasok kebutuhan asupan protein hewani bagi manusia. Konsumsi protein hewani asal daging masyarakat Indonesia dari tahun ke tahun mengalami peningkatan dengan pemenuhan sebagian besar kebutuhan berasal dari daging ayam broiler. Populasi ayam broiler sampai tahun 2013 mencapai angka 1,3 miliar ekor (BPS 2014).

Daging ayam broiler merupakan jenis daging yang paling banyak dikonsumsi oleh masyarakat Indonesia. Data dari Kementerian Pertanian (2014) menunjukkan konsumsi daging ayam broiler per kapita di Indonesia mengalami pertumbuhan yang positif setiap tahunnya dibandingkan jenis-jenis daging lain. Rataan pertumbuhan konsumsi daging ayam broiler adalah sebesar $0,144 \mathrm{~kg}$ per kapita per tahun. Peningkatan konsumsi tersebut disebabkan karena pertambahan jumlah penduduk, peningkatan pendapatan per kapita dan harga daging ayam broiler yang lebih terjangkau dibandingkan jenis daging lain.

Pertumbuhan populasi dan peningkatan konsumsi daging ayam broiler di Indonesia tidak diikuti dengan meningkatnya teknologi transportasi memadai berdasarkan pencemaran lingkungan yang ditimbulkan dan faktor kesejahteraan ayam broiler. Keadaan pada saat ini, pengangkutan ayam broiler hanya menggunakan keranjang terbuka yang disiram dengan air sebagai upaya untuk mengurangi stres panas yang dialami oleh ayam selama pengangkutan. Kesejahteraan ternak dan pencemaran lingkungan yang ditimbulkan sangat minim diperhatikan. Pengangkutan yang tidak sesuai dengan kesejahteraan ternak juga dapat menimbulkan stres panas yang berakibat terhadap penurunan bobot badan ayam selama pengangkutan. Kondisi nyaman pada ayam broiler menurut Suharti (2004) adalah ayam dalam kondisi diam atau berbaring, leher dijulurkan, mata tertutup atau kadangkadang menutup dan membuka, sayap terkulai dijatuhkan, dan tidur (kepala ditarik ke dalam bulu di atas atau di belakang sayap), sehingga diperlukan pengembangan teknologi transportasi ayam yang dapat mengurangi tingkat stres ayam selama perjalanan.

Perancangan model pengangkutan ayam broiler yang memperhatikan kesejahteraan ternak dan pencemaran lingkungan sudah pernah dilaksanakan, namun belum mendapatkan hasil yang maksimal. Respon fisiologis ayam broiler yang diangkut menggunakan sistem transportasi konvensional (terbuka) dengan transportasi tertutup (M-CLOVE) perlu diteliti untuk mendesain sistem pengangkutan ayam broiler yang memastikan kesejahteraan ternak dan mengurangi efek stres yang dialami ayam broiler selama perjalanan. Penelitian ini bertujuan untuk membandingkan tingkat stres ayam broiler berdasarkan suhu jengger, suhu shank, dan suhu rektal pada sistem pengangkutan konvensional dengan sistem ramah lingkungan M-CLOVE dan jenis kelamin yang berbeda. 


\section{MATERI DAN METODE}

Waktu dan Tempat Penelitian

Penelitian ini dilaksanakan di kampus IPB Dramaga, Desa Babakan, Kecamatan Dramaga, Kabupaten Bogor. Penelitian dilaksanakan mulai tanggal 1 sampai 30 Juni 2015.

\section{Bahan}

Bahan yang digunakan pada penelitian ini adalah sekam padi, vitachick, gula merah, pakan ayam broiler, dan ayam broiler siap panen umur 30 hari sebanyak 10 ekor jantan dan 10 ekor betina dengan rataan bobot badan awal $1203,8 \pm 125,90 \mathrm{~kg}$.

\section{Alat}

Peralatan yang digunakan pada penelitian ini adalah mobil bak terbuka, keranjang ayam konvensional, kipas laptop, tempat pakan ayam, tempat minum ayam, mini closed house vehicle dengan spesifikasi dimensi (ukuran) $1,35 \mathrm{~m} \times 2,95 \mathrm{~m} \times 1,75 \mathrm{~m}$ dengan volume tampung $1,30 \mathrm{~m}$ x 1,85 m x 1,70 m, pita, digital thermohygrometer, APPA digital thermometer, dan infrared thermometer.

\section{Prosedur}

Penelitian diawali dengan menyiapkan mobil bak terbuka yang mengangkut M-CLOVE dan keranjang ayam konvensional sebagai faktor perlakuan pertama. Bagian dasar M-CLOVE diisi menggunakan sekam padi sebagai reaktor organik penyerap bau. Ayam yang digunakan adalah ayam broiler siap panen berumur 30 hari berjumlah 10 ekor jantan dan 10 ekor betina. Masing-masing keranjang diisi ayam broiler sebanyak 5 ekor jantan dan 5 ekor betina sebagai faktor perlakuan kedua.

Peubah yang diamati adalah suhu shank, suhu jengger, suhu rektal, suhu dan kelembaban relatif di dalam dan di luar alat pengangkut. Sebelum proses pengangkutan suhu shank, suhu jengger dan suhu rektal dari seluruh sampel diukur. Suhu shank dan suhu jengger diukur menggunakan infrared thermometer yang langsung diarahkan ke bagian permukaan jengger dan shank ayam, sedangkan suhu rektal diukur dengan menggunakan APPA digital thermometer yang dimasukkan ke dalam rektal ayam hingga suhu pada termometer tetap. Suhu dan kelembaban relatif di dalam dan di luar alat pengangkut diukur menggunakan thermohygrometer digital.

Pengangkutan dilakukan dengan lama waktu 1 jam perjalanan dengan kecepatan kendaraan stabil $40 \mathrm{~km}$ $\mathrm{jam}^{-1}$. Suhu dan kelembaban relatif di dalam dan di luar alat pengangkut diukur dalam interval 30 menit selama proses pengangkutan. Selama dan setelah pengangkutan, dilakukan pengukuran suhu dan kelembaban relatif di dalam dan di luar alat pengangkut, serta suhu shank, suhu jengger, suhu rektal diukur kembali sebagai data respon fisiologis ayam setelah mengalami proses pengangkutan. Ayam broiler diistirahatkan selama 5 hari sebagai upaya untuk mengembalikan keadaan fisiologis kembali normal. Pengistirahatan ayam broiler dilakukan dengan mengkandangkan dan memberi pakan sesuai kebutuhan dengan air minum yang selalu tersedia. Proses pengangkutan dilakukan kembali pada ayam broiler umur 35 dan 40 hari. Ulangan didapatkan dari pengangkutan pada umur ayam yang berbeda.

\section{Analisis Data}

Rancangan yang digunakan adalah Rancangan Acak Kelompok pola Faktorial dengan 2 faktor dan masingmasing faktor terdiri atas 3 ulangan. Faktor yang pertama adalah sistem transportasi yakni keranjang konvensional dan sistem tertutup ramah lingkungan M-CLOVE. Faktor kedua adalah perbedaan jenis kelamin ayam broiler jantan dan betina, sedangkan ulangan adalah 3 kali proses transportasi pada umur ayam yang berbeda. Model matematis yang digunakan menurut Walpole (1993) adalah sebagai berikut:

$$
Y_{i j k}=\mu+T_{i}+S_{j}+K_{k}+T_{i j}+\varepsilon_{i j k}
$$

Keterangan:

$\mathrm{Y}_{\mathrm{ijk}}=$ variabel respon akibat pengaruh sistem transportasi ke-i (keranjang dan M-CLOVE) dan jenis kelamin ke-j (jantan dan betina) pada ulangan ke-k $(1,2,3)$

$\mu \quad=$ nilai tengah umum (suhu shank, suhu jengger dan suhu rektal) ayam broiler

$\mathrm{T}_{\mathrm{i}} \quad=$ pengaruh sistem transportasi ke-i (keranjang dan M-CLOVE)

$\mathrm{S}_{\mathrm{j}} \quad=$ pengaruh jenis kelamin ke-j (jantan dan betina)

$\mathrm{K}_{\mathrm{k}} \quad=$ pengaruh kelompok umur ke-k (30 hari, 35 hari dan 40 hari)

$\mathrm{TS}_{\mathrm{ij}} \quad=$ pengaruh interaksi antara sistem transportasi ke-i (keranjang dan M-CLOVE) dengan jenis kelamin ke-j (jantan dan betina)

$\varepsilon_{\mathrm{ijk}} \quad=$ pengaruh galat percobaan pada unit percobaan ke-k (30 hari, 35 hari dan 40 hari) dalam kombinasi perlakuan ke-i (keranjang dan M-CLOVE) dan ke-j (jantan dan betina)

Data yang diperoleh dianalisis ragam (ANOVA). Uji lanjut Tukey dilakukan pada taraf $95 \%$.

\section{HASIL DAN PEMBAHASAN}

\section{Sistem Pengangkutan M- CLOVE dan Keranjang Konvensional}

Iklim merupakan salah satu faktor lingkungan yang berpengaruh langsung dan tidak langsung terhadap ternak. Selain itu, berbeda dengan faktor lingkungan yang lain seperti pakan dan kesehatan, iklim tidak dapat diatur atau dikuasai sepenuhnya oleh manusia. Ayam broiler merupakan golongan ternak unggas yang memiliki tingkat stres yang tinggi terutama akibat panas selama berada transportasi sehingga diperlukan sistem pengangkutan yang dapat mengurangi tingkat stres ayam broiler.

M-CLOVE merupakan alat angkut ayam yang didesain dapat mengantisipasi keadaan yang terjadi saat transportasi, seperti cuaca panas dan dingin (Gambar 1). Ketika cuaca panas, kipas laptop akan mengatur kondisi 
suhu dalam box sehingga panas dalam box dapat dikurangi. Model M-CLOVE mengadopsi seperti model box mobil konvensional yang telah dimodifikasi. Mobil yang digunakan jenis pick up atau sejenisnya. Kotak penutup utama dibuat dari bahan utama berupa papan triplek kayu dengan spesifikasi dimensi (ukuran) 1,35 m x 2,95 m x $1,75 \mathrm{~m}$ dengan volume tampung $1,30 \mathrm{~m} \times 1,85 \mathrm{~m} \times 1,70 \mathrm{~m}$. Pada bagian atas depan (bagian atas kepala mobil) ukuran penutup dilebihkan ke depan untuk memberikan celah bagi cerobong angin. Akses bongkar muat keranjang ayam terdapat pada bagian samping.

Bagian dalam M-CLOVE merupakan tempat utama untuk meletakkan keranjang-keranjang ayam. Pada bagian ini lokasi penempatan keranjang dibuat menjadi 3 tingkatan seperti yang terlihat pada Gambar 2. Tingkat pertama dan kedua merupakan tempat pengangkutan ayam yang berisi masing-masing 1 buah keranjang ayam. Tingkat terbawah ditempatkan kotak reaktor yang berisi bahan- bahan organik yang berfungsi menyerap bau yang ditimbulkan dari kotoran ayam. Reaktor terbuat dari papan kayu dengan ukuran 2,95 $\mathrm{m} \times 1,35 \mathrm{~m}$. Reaktor tersebut berisi sekam padi. Terdapat ventilasi pada bagian samping dan belakang M-CLOVE sebagai sumber sirkulasi udara.

Pengangkutan ayam konvensional merupakan pengangkutan yang menggunakan keranjang ayam konvensional yang disusun pada mobil pengangkut jenis pick up atau truk (Gambar 3). Pengangkutan konvensional tidak dapat melindungi ayam dari panas maupun hujan pada saat proses pengangkutan sehingga dapat membuat cekaman stres pada ayam meningkat. Keranjang ayam konvensional berukuran $95 \mathrm{~cm}$ x $50 \mathrm{~cm}$ x $25 \mathrm{~cm}$. Jumlah ayam dalam sekali pengangkutan maksimum 15 ekor pada bobot 1 ekor ayam adalah $2 \mathrm{~kg}$ (Medion 2015).

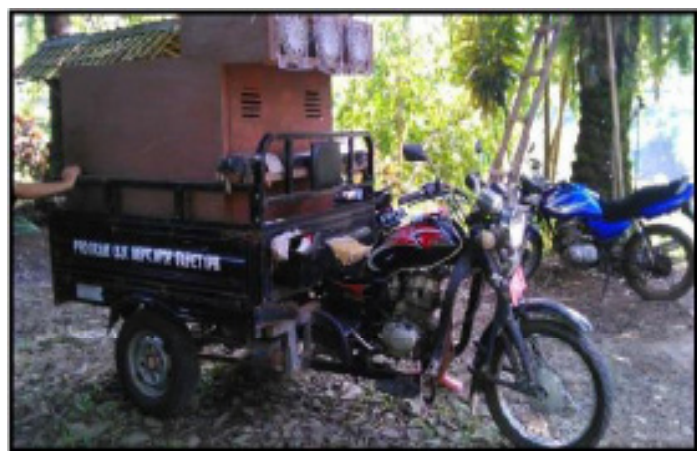

Gambar 1 Tampilan luar alat angkut M-CLOVE

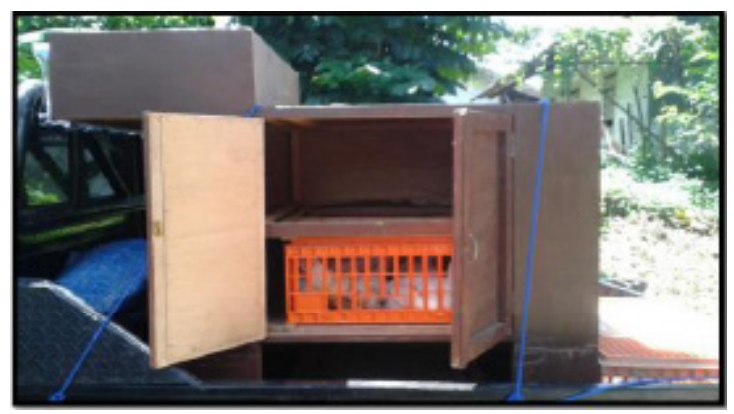

Gambar 2 Tampilan dalam alat angkut M-CLOVE

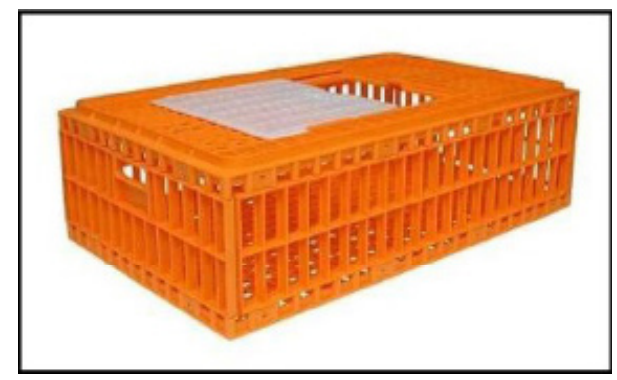

Gambar 3 Keranjang konvensional

Stres panas merupakan salah satu kendala yang mempengaruhi produktivitas ternak ayam broiler. Suhu tubuh normal ayam broiler adalah sekitar $41{ }^{\circ} \mathrm{C}$. Bila suhu lingkungan melebihi $35^{\circ} \mathrm{C}$, ayam broiler akan mengalami stress panas (Aviagen 2012). Semakin lama broiler terpapar suhu tinggi, semakin besar stres dan dampaknya.

Ayam broiler dapat hidup nyaman pada suhu lingkungan yang sesuai dengan kebutuhannya. Peningkatan suhu harian yang ekstrim akan berakibat buruk terhadap kesehatan dan performa ayam. Menurut Kusnadi (2006), peningkatan suhu lingkungan melebihi kisaran zona suhu kenyamanan menyebabkan stres pada ayam broiler.

Suhu dan kelembaban lingkungan pada Tabel 1 merupakan data suhu dan kelembaban lingkungan di luar sistem pengangkutan M-CLOVE dan keranjang konvensional. Suhu lingkungan lebih rendah daripada suhu pada M-CLOVE dan kerangjang konvensional. Mujahid et al. (2007) menyatakan peningkatan suhu lingkungan $5{ }^{\circ} \mathrm{C}$ yang melebihi kisaran zona suhu nyaman menyebabkan stress oksidatif (kondisi radikal bebas melebihi antioksidan) pada ayam broiler. Udara panas mengakibatkan panas dilepaskan melalui proses evaporasi (penguapan melalui udara pernafasan) bahkan mengalami panting (mengapmengap), serta peningkatan suhu tubuh karena cekaman yang mengakibatkan metabolisme tidak berjalan optimal karena energi yang dihasilkan dari metabolisme hanya dibuang ke lingkungan menjadi panas yang akan terakumulasi pada sistem alat angkut M-CLOVE dan keranjang konvensional, sehingga suhu pada M-CLOVE dan keranjang konvensional lebih tinggi.

Suhu dan kelembaban relatif saling berhubungan dalam mempengaruhi tingkat kenyamanan dari ayam broiler. Rataan suhu pada kandang pemeliharaan atau kandang pemulihan kondisi ayam selama masa penelitian tercatat $30,6 \pm 1,53{ }^{\circ} \mathrm{C}$ dengan tingkat kelembaban relatif mencapai $82,7 \pm 8,02 \%$. Suhu kandang tersebut menurut Aviagen (2012) masih dapat ditoleransi oleh ayam broiler karena masih berada di bawah suhu $35{ }^{\circ} \mathrm{C}$, sehingga ayam broiler masih dalam lingkungan yang nyaman selama masa pemulihan.

Rataan suhu dan kelembaban relatif selama proses transportasi pada M- CLOVE lebih rendah dibandingkan dengan keranjang konvensional (Tabel 2). Perbedaan suhu yang terjadi sebesar $1,4{ }^{\circ} \mathrm{C}$ dengan perbedaan kelembaban relatif $2,5 \%$. Perbedaan tersebut dikarenakan M-CLOVE merupakan alat angkut dengan desain tertutup sehingga terlindung dari paparan sinar matahari langsung dan memiliki sirkulasi dengan kipas yang dapat menjaga suhu 
Tabel 1 Suhu dan kelembaban relatif rata-rata selama proses penelitian

\begin{tabular}{lcccccc}
\hline $\begin{array}{c}\text { Umur } \\
\text { (hari) }\end{array}$ & Suhu $\left({ }^{\circ} \mathrm{C}\right)$ & Kelembaban Relatif $(\%)$ & Suhu $\left({ }^{\circ} \mathrm{C}\right)$ & Kelembaban Relatif $(\%)$ & Suhu $\left({ }^{\circ} \mathrm{C}\right)$ & Kelembaban Relatif $(\%)$ \\
\hline 30 & $31,13 \pm 1,59$ & $70,0 \pm 12,17$ & $33,6 \pm 1,28$ & $67,0 \pm 7,00$ & $35,7 \pm 0,26$ & $68,0 \pm 11,27$ \\
35 & $29,4 \pm 0,46$ & $68,3 \pm 10,41$ & $32,9 \pm 1,11$ & $59,0 \pm 9,54$ & $34,7 \pm 1,61$ & $61,0 \pm 7,00$ \\
40 & $31,4 \pm 1,18$ & $68,7 \pm 10,69$ & $35,5 \pm 1,81$ & $62,0 \pm 7,81$ & $35,7 \pm 1,73$ & $67,0 \pm 7,00$ \\
\hline Rataan & $30,6 \pm 1,09$ & $69,0 \pm 0,88$ & $34,0 \pm 1,35$ & $62,67 \pm 4,31$ & $35,4 \pm 0,58$ & $65,33 \pm 3,79$ \\
\hline
\end{tabular}

Tabel 2 Suhu, kelembaban relatif dan kecepatan udara yang diukur interval 30 menit

\begin{tabular}{|c|c|c|c|c|c|}
\hline \multirow[t]{2}{*}{ Jenis alat } & \multirow[t]{2}{*}{ Peubah } & \multirow[t]{2}{*}{ Menit } & \multicolumn{3}{|c|}{ Umur (hari) } \\
\hline & & & 30 & 35 & 40 \\
\hline \multirow[t]{9}{*}{ M-CLOVE } & Suhu $\left({ }^{\circ} \mathrm{C}\right)$ & 0 & 32,3 & 31,9 & 33,6 \\
\hline & & 30 & 34,7 & 32,7 & 35,7 \\
\hline & & 60 & 33,9 & 34,1 & 37,2 \\
\hline & Kelembaban relatif $(\%)$ & 0 & 75 & 70 & 71 \\
\hline & & 30 & 64 & 54 & 57 \\
\hline & & 60 & 62 & 53 & 58 \\
\hline & Kecepatan udara (m/detik) & 0 & 0 & 0 & 0 \\
\hline & & 30 & 10,28 & 11,67 & 10,55 \\
\hline & & 60 & 0 & 0 & 0 \\
\hline \multirow[t]{9}{*}{ Keranjang Konvensional } & Suhu $\left({ }^{\circ} \mathrm{C}\right)$ & 0 & 31,8 & 33,2 & 34,2 \\
\hline & & 30 & 32,3 & 34,5 & 35,3 \\
\hline & & 60 & 31,9 & 36,4 & 37,6 \\
\hline & Kelembaban relatif $(\%)$ & 0 & 83 & 69 & 75 \\
\hline & & 30 & 64 & 58 & 64 \\
\hline & & 60 & 63 & 56 & 62 \\
\hline & Kecepatan udara (m/detik) & 0 & 0 & 0 & 0 \\
\hline & & 30 & 10,28 & 11,67 & 10,55 \\
\hline & & 60 & 0 & 0 & 0 \\
\hline \multirow[t]{9}{*}{ Lingkungan } & Suhu $\left({ }^{\circ} \mathrm{C}\right)$ & 0 & 29,3 & 29 & 30,1 \\
\hline & & 30 & 32,2 & 29,3 & 31,7 \\
\hline & & 60 & 31,9 & 29,9 & 32,4 \\
\hline & Kelembaban relatif $(\%)$ & 0 & 84 & 80 & 81 \\
\hline & & 30 & 64 & 60 & 63 \\
\hline & & 60 & 62 & 65 & 62 \\
\hline & Kecepatan udara (m/detik) & 0 & 0 & 0 & 0 \\
\hline & & 30 & 10,28 & 11,67 & 10,55 \\
\hline & & 60 & 0 & 0 & 0 \\
\hline
\end{tabular}

Keterangan: angka 0 pada parameter kecepatan udara disebabkan karena pengukuran tidak terbaca oleh alat.

dan kelembaban relatif dalam M-CLOVE konstan. Alat angkut keranjang konvensional tidak memiliki perlindungan sama sekali terhadap paparan sinar matahari langsung, sehingga tubuh ayam broiler terpapar panas langsung dari sinar matahari yang akan meningkatkan suhu tubuh ayam broiler.

Kondisi stres pada ayam terjadi selama proses pengangkutan. Tingkat stres yang tinggi selama proses pengangkutan dipengaruhi oleh beberapa faktor antara lain suhu, kelembaban, serta ventilasi mobil pengangkut yang berdampak pada peningkatan kematian. Kondisi mobil pengangkut dapat menyebabkan stres pada broiler sehingga menurunkan kualitas daging (Olivo et al. 2001)

\section{Peningkatan Suhu Jengger pada Proses Pengangkutan}

Ayam broiler memiliki pertumbuhan dan laju metabolisme yang cepat disertai produksi panas yang tinggi akibat tingginya konsumsi pakan. Ayam adalah salah satu hewan homeotermik yang memiliki kemampuan untuk mempertahankan suhu tubuhnya relatif stabil pada suatu kisaran suhu yang sempit walaupun terjadi perubahan suhu yang besar pada lingkungan (Yahav et al. 2004). Salah satu proses pelepasan panas tubuh ayam broiler adalah dengan proses evaporasi melalui permukaan tubuh ayam broiler (Diding dan Andi 2011) diantaranya melalui jengger (Tabel 3).

Ayam broiler dapat melakukan aktifitas pada suhu 
lingkungan yang berbeda akibat dari kemampuan mengatur suhu tubuhnya. Ayam mempunyai variasi temperatur normal yang dipengaruhi oleh faktor umur, faktor kelamin, faktor lingkungan, faktor panjang waktu siang dan malam dan faktor makanan yang dikonsumsi (Yahav et al. 2004). Jengger merupakan bagian tubuh yang melepaskan panas lebih tinggi dibanding organ yang lain (Diding dan Andi 2011). Hasil penelitian menunjukkan bahwa respon permukaan tubuh ayam broiler pada bagian jengger dalam melepaskan panas tubuh pada alat angkut M-CLOVE berbeda $(\mathrm{P}<0,05)$ dengan ayam broiler yang diangkut menggunakan keranjang konvensional. Peningkatan suhu jengger lebih tinggi pada ayam broiler yang diangkut menggunakan keranjang konvensional daripada M-CLOVE (Tabel 3). Namun, perbedaan jenis kelamin serta kelompok tidak berbeda antara ayam broiler yang diangkut menggunakan M-CLOVE dengan ayam broiler yang diangkut menggunakan keranjang konvensional. Perbedaan peningkatan suhu jengger diakibatkan paparan sinar matahari yang lebih intensif pada ayam broiler yang hanya diangkut menggunakan keranjang ayam konvensional. Tingginya paparan sinar matahari akan meningkatkan suhu tubuh ayam.

Proses homeostatis terjadi melalui proses peredaran darah. Darah merupakan cairan tubuh yang berfungsi menjaga temperatur tubuh (Dawson dan Whittow 2000). Rahardja (2010) mengemukakan pada umumnya, pembuluh darah yang menjadi tempat cadangan sejumlah darah dihubungkan oleh cabang serabut saraf symphatetik yang perangsangannya menyebabkan vasokontriksi, dan mengalihkan pengaliran darah ke bagian lain. Perubahan proporsi darah yang mengalir menuju pembuluh darah kapiler antara lain dipengaruhi oleh suhu sebagai mekanisme rangsangan saraf symphatetik untuk mengeluarkan panas tubuh dalam rangka mempertahankan suhu tubuh ternak (Mutaf et al. 2008).

Peningkatan Suhu Shank pada Proses Pengangkutan

Suhu shank dapat digunakan sebagai salah satu indikator respon fisiologis. Suhu shank akan meningkat seiring dengan peningkatan suhu lingkungan. Peningkatan suhu shank diakibatkan perubahan volume darah yang mengalir menuju pembuluh darah kapiler. Ternak akan mempertahankan suhu tubuh agar tetap berada pada kondisi normal melalui mekanisme rangsangan saraf symphatetik untuk mengeluarkan panas tubuh berlebih (Mutaf et al. 2008). Hal ini menyebabkan organ-organ yang memiliki pembuluh darah kapiler yang banyak (termasuk shank) akan efektif sebagai organ yang mengevaporasikan panas lebih tinggi, dengan meningkatkan laju alir dan volume darah ke organ-organ tersebut (Shinder et al. 2007). Saat suhu lingkungan tinggi tubuh akan mendistribusikan darah ke pembuluh darah permukaan untuk menghilangkan panas. Semakin banyak darah dari bagian tengah tubuh yang mencapai kulit, semakin dekat suhu kulit dengan suhu inti. Pembuluh darah kulit menghilangkan efektivitas kulit sebagai isolator dengan mengangkut panas ke permukaan, tempat panas tersebut dapat dikeluarkan dari tubuh melalui radiasi, konduksi, dan konveksi (Shinder et al. 2007).

Hasil penelitian menunjukkan peningkatan suhu shank ayam broiler yang diangkut menggunakan M-CLOVE berbeda nyata $(\mathrm{P}<0,05)$ dibandingkan dengan ayam broiler yang diangkut menggunakan keranjang konvensional (Tabel 4). Peningkatan suhu shank yang lebih tinggi pada ayam broiler yang diangkut menggunakan keranjang konvensional terjadi karena tingginya paparan sinar matahari dibandingkan dengan ayam broiler yang diangkut menggunakan M- CLOVE.

Suhu lingkungan yang tinggi meningkatkan suhu tubuh ayam. Peningkatan fungsi organ tubuh dan alat pernafasan merupakan akibat dari aktifitas metabolisme basal pada suhu lingkungan tinggi (Yousef 1984).

Hasil penelitian juga menunjukkan kelompok (usia ayam broiler) 35 hari berbeda $(\mathrm{P}<0,05)$ dengan kelompok pengangkutan ayam umur 30 dan 40 hari. Hal tersebut diakibatkan pada masing-masing periode pertumbuhan, suhu tubuh ayam broiler berbeda karena proses metabolisme di

Tabel 3 Peningkatan suhu $\left({ }^{\circ} \mathrm{C}\right)$ jengger ayam broiler pada proses pengangkutan

\begin{tabular}{|c|c|c|c|c|c|c|c|}
\hline \multirow[t]{2}{*}{ Jenis alat } & \multirow{2}{*}{$\begin{array}{c}\text { Jenis } \\
\text { kelamin }\end{array}$} & & \multicolumn{3}{|c|}{ Umur (hari) } & \multirow[t]{2}{*}{ Rataan } & \multirow[t]{2}{*}{ Rataan } \\
\hline & & & 30 & 35 & 40 & & \\
\hline \multirow[t]{6}{*}{ M-ClOVE } & Jantan & Sebelum pengangkutan & $37,2 \pm 0,90$ & $35,4 \pm 0,86$ & $36,8 \pm 0,64$ & $36,5 \pm 0,95$ & \multirow{6}{*}{$0,67 \pm 0,06$} \\
\hline & & Sesudah pengangkutan & $38,1 \pm 0,61$ & $37,5 \pm 1,01$ & $37,7 \pm 0,51$ & $37,8 \pm 0,31$ & \\
\hline & & Selisih suhu & $0,86 \pm 0,43$ & $0,34 \pm 0,50$ & $0,94 \pm 0,55$ & $0,71 \pm 0,33$ & \\
\hline & \multirow[t]{3}{*}{ Betina } & Sebelum pengangkutan & $37,3 \pm 0,97$ & $35,0 \pm 1,85$ & $36,2 \pm 0,86$ & $36,2 \pm 1,15$ & \\
\hline & & Sesudah pengangkutan & $38,2 \pm 1,03$ & $35,6 \pm 2,05$ & $36,7 \pm 0,54$ & $36,8 \pm 1,31$ & \\
\hline & & Selisih suhu & $0,90 \pm 0,25$ & $0,54 \pm 1,88$ & $0,44 \pm 0,54$ & $0,63 \pm 0,24$ & \\
\hline \multirow[t]{6}{*}{ Keranjang konvensional } & Jantan & Sebelum pengangkutan & $36,6 \pm 0,72$ & $33,1 \pm 1,31$ & $37,2 \pm 0,43$ & $35,6 \pm 2,21$ & \multirow{6}{*}{$1,99 \pm 0,77 \mathrm{a}$} \\
\hline & & Sesudah pengangkutan & $39,6 \pm 0,36$ & $36,2 \pm 2,42$ & $38,8 \pm 0,60$ & $38,2 \pm 1,78$ & \\
\hline & & Selisih suhu & $2,92 \pm 0,79$ & $3,08 \pm 2,48$ & $1,60 \pm 0,81$ & $2,53 \pm 0,81$ & \\
\hline & Betina & Sebelum pengangkutan & $36,7 \pm 1,12$ & $34,3 \pm 0,60$ & $36,6 \pm 0,54$ & $35,9 \pm 1,36$ & \\
\hline & & Sesudah pengangkutan & $38,6 \pm 0,99$ & $35,9 \pm 1,73$ & $37,4 \pm 0,60$ & $37,3 \pm 1,35$ & \\
\hline & & Selisih suhu & $1,96 \pm 1,93$ & $1,62 \pm 1,98$ & $0,74 \pm 0,09$ & $1,44 \pm 0,63$ & \\
\hline Rataan & & & $1,66 \pm 0,98$ & $1,40 \pm 1,26$ & $0,93 \pm 0,49$ & & \\
\hline
\end{tabular}

Keterangan: angka-angka pada baris yang sama dengan hurus yang berbeda adalah berbeda nyata $(\mathrm{P}<0,05)$; selisih suhu menunjukan perbedaan suhu sebelum pengangkutan dengan setelah pengangkutan. 
Tabel 4 Peningkatan suhu $\left({ }^{\circ} \mathrm{C}\right)$ shank ayam broiler pada proses pengangkutan

\begin{tabular}{|c|c|c|c|c|c|c|c|}
\hline \multirow[t]{2}{*}{ Jenis alat } & \multirow{2}{*}{$\begin{array}{c}\text { Jenis } \\
\text { kelamin }\end{array}$} & & \multicolumn{3}{|c|}{ Umur (hari) } & \multirow[t]{2}{*}{ Rataan } & \multirow[t]{2}{*}{ Rataan } \\
\hline & & & 30 & 35 & 40 & & \\
\hline \multirow[t]{6}{*}{ M-CLOVE } & Jantan & Sebelum pengangkutan & $35,3 \pm 1,06$ & $31,9 \pm 1,48$ & $33,4 \pm 0,70$ & $33,6 \pm 1,70$ & \multirow{6}{*}{$1,52 \pm 0,20 \mathrm{~b}$} \\
\hline & & Sesudah pengangkutan & $36,7 \pm 1,39$ & $34,2 \pm 2,09$ & $34,7 \pm 0,86$ & $35,2 \pm 1,32$ & \\
\hline & & Selisih suhu & $1,40 \pm 1,37$ & $2,30 \pm 1,47$ & $1,28 \pm 0,83$ & $1,66 \pm 0,56$ & \\
\hline & \multirow[t]{3}{*}{ Betina } & Sebelum pengangkutan & $34,7 \pm 0,83$ & $35,3 \pm 3,11$ & $33,2 \pm 0,33$ & $34,4 \pm 1,08$ & \\
\hline & & Sesudah pengangkutan & $36,0 \pm 1,81$ & $37,1 \pm 2,30$ & $34,3 \pm 0,56$ & $35,8 \pm 1,41$ & \\
\hline & & Selisih suhu & $1,32 \pm 1,53$ & $1,76 \pm 1,57$ & $1,06 \pm 0,44$ & $1,38 \pm 0,35$ & \\
\hline \multirow[t]{6}{*}{ Keranjang konvensional } & Jantan & Sebelum pengangkutan & $36,6 \pm 0,83$ & $32,2 \pm 2,16$ & $34,4 \pm 0,43$ & $34,4 \pm 2,20$ & \multirow{6}{*}{$2,83 \pm 0,42 \mathrm{a}$} \\
\hline & & Sesudah pengangkutan & $38,3 \pm 0,77$ & $35,9 \pm 2,63$ & $36,6 \pm 0,46$ & $36,9 \pm 1,23$ & \\
\hline & & Selisih suhu & $1,72 \pm 1,34$ & $3,68 \pm 1,79$ & $2,18 \pm 0,31$ & $2,53 \pm 1,02$ & \\
\hline & \multirow[t]{3}{*}{ Betina } & Sebelum pengangkutan & $36,9 \pm 0,76$ & $32,2 \pm 0,68$ & $34,6 \pm 0,35$ & $34,6 \pm 2,35$ & \\
\hline & & Sesudah pengangkutan & $38,9 \pm 0,70$ & $37,1 \pm 1,34$ & $37,2 \pm 0,75$ & $37,7 \pm 1,01$ & \\
\hline & & Selisih suhu & $1,96 \pm 1,21$ & $4,88 \pm 1,17$ & $2,56 \pm 0,54$ & $3,13 \pm 1,54$ & \\
\hline Rataan & & & $1,60 \pm 0,30 \mathrm{~b}$ & $3,16 \pm 0,41 \mathrm{a}$ & $1,77 \pm 0,72 b$ & & \\
\hline
\end{tabular}

Keterangan: angka-angka pada baris yang sama dengan hurus yang berbeda adalah berbeda nyata $(\mathrm{P}<0,05)$; selisih suhu menunjukan perbedaan suhu sebelum pengangkutan dengan setelah pengangkutan.

dalam tubuh tidak selalu tetap.

Perbedaan metabolisme salah satunya dipengaruhi oleh umur (Diding dan Andi 2011). Perbedaan kondisi mikroklimat selama proses pengangkutan juga dapat mengakibatkan perbedaan respon fisiologis yang ditunjukkan oleh ternak. Semakin tinggi suhu dan kelembaban relatif pada proses transportasi akan meningkatkan suhu tubuh ayam broiler. Perbedaan aktivitas metabolisme akan menunjukkan respon yang berbeda dalam mempertahankan suhu tubuhnya. Perbedaan jenis kelamin pada proses pengangkutan tidak berbeda nyata.

\section{Peningkatan Suhu Rektal pada Proses Pengangkutan}

Cekaman panas merupakan kondisi saat ternak mengalami kesulitan untuk mempertahankan keseimbangan produksi dan pembuangan panas tubuh (Yahav et al. 2004). Ayam akan memproduksi panas dan membuang kelebihan panas tubuh secara terkendali pada zona termonetral sehingga suhu tubuh konstan. Hewan homeotermik memiliki pengatur panas tubuh yang telah berkembang baik. Suhu rektal pada ternak dipengaruh beberapa faktor yaitu suhu lingkungan, aktivitas, makan, minuman dan pencernaan (Kartasudjana 2005). Suhu rektal digunakan sebagai ukuran suhu tubuh karena suhu rektal menunjukkan pengukur suhu tubuh ayam yang akurat (Yayu dan Dahono 2013). Tabel 5 merupakan peningkatan suhu rektal ayam broiler yang terjadi selama proses transportasi berlangsung.

Suhu rektal dapat digunakan sebagai salah satu indikator respon fisiologi ayam broiler. Suhu rektal ayam broiler setelah pengangkutan menggunakan sistem keranjang konvensional berbeda $(\mathrm{P}<0,05)$ dibandingkan dengan pengangkutan menggunakan M-CLOVE. Tingginya suhu rektal ayam broiler pada pengangkutan menggunakan keranjang konvensional diduga dipengaruhi penerimaan panas dari sinar matahari yang lebih tinggi. Pengangkutan sistem terbuka menyebabkan penerimaan radiasi panas lebih tinggi dibandingkan sistem tertutup (Mitchell dan Kettlewell 1998). Beberapa faktor yang berpengaruh terhadap peningkatan suhu rektal adalah lingkungan, aktivitas, pakan, minuman, dan pencernaan (Filho et al. 2007). Tingginya suhu rektal menjadi indikasi terjadinya cekaman panas pada ayam broiler selama pengangkutan. Filho et al. (2007) menyatakan selama transportasi, ayam dapat mengalami stres, termasuk peningkatan suhu rektal, sehingga menyebabkan penurunan bobot badan dan peningkatan kematian.

Suhu rektal yang ditunjukkan pada jenis kelamin betina berbeda nyata $(\mathrm{P}<0,05)$ dibandingkan dengan suhu rektal ayam berjenis kelamin jantan (Tabel 5). Peningkatan suhu rektal ayam berjenis kelamin jantan lebih tinggi dibandingkan dengan ayam betina. Hal tersebut diduga karena metabolisme ayam jantan berlangsung lebih tinggi dibandingkan dengan metabolisme ayam betina. Suhu tubuh dapat diketahui dengan mengukur suhu pada rektal.

Perubahan suhu rektal pada ayam merupakan salah satu pengaruh dari mekanisme thermoregulasi yang dilakukan oleh tubuh ternak dalam rangka mempertahankan suhu tubuhnya. Menurut Yahav et al. (2004), ayam mempunyai variasi temperatur normal yang dipengaruhi oleh umur, kelamin, lingkungan, panjang waktu siang, dan malam serta makanan yang dikonsumsi. Selain itu, penempatan ayam betina dan jantan dalam satu keranjang juga diduga berpengaruh, karena perbedaan kebutuhan ruangan yang lebih tinggi pada ternak jantan dapat menimbulkan cekaman stres.

\section{Perbandingan Peningkatan Suhu Jengger, Suhu Shank dan Suhu Rektal}

Ayam broiler memiliki pertumbuhan dan laju metabolisme yang cepat, disertai dengan produksi panas yang tinggi akibat tingginya konsumsi pakan. Ayam bersifat homeotermik dan mempertahankan suhu tubuh pada rentangan yang sempit, kemampuan mendisipasi panas menurun saat temperatur lingkungan meningkat (Yahav et al. 2004). Pada temperatur lingkungan yang 
Tabel 5 Peningkatan suhu $\left({ }^{\circ} \mathrm{C}\right)$ rektal ayam broiler pada proses pengangkutan

\begin{tabular}{|c|c|c|c|c|c|c|c|}
\hline \multirow[t]{2}{*}{ Jenis alat } & \multirow{2}{*}{$\begin{array}{c}\text { Jenis } \\
\text { kelamin }\end{array}$} & & \multicolumn{3}{|c|}{ Umur (hari) } & \multirow[t]{2}{*}{ Rataan } & \multirow[t]{2}{*}{ Rataan } \\
\hline & & & 30 & 35 & 40 & & \\
\hline \multirow[t]{6}{*}{ M-CLOVE } & \multirow[t]{3}{*}{ Jantan } & Sebelum pengangkutan & $39,9 \pm 0,55$ & $39,5 \pm 1,00$ & $40,3 \pm 1,23$ & $39,9 \pm 0,40$ & \multirow{6}{*}{$1,25 \pm 0,42 b$} \\
\hline & & Sesudah pengangkutan & $41,4 \pm 0,38$ & $41,1 \pm 0,73$ & $41,9 \pm 1,12$ & $41,5 \pm 0,40$ & \\
\hline & & Selisih suhu & $1,44 \pm 0,21$ & $1,60 \pm 0,40$ & $1,60 \pm 0,37$ & $1,55 \pm 0,09$ & \\
\hline & \multirow[t]{3}{*}{ Betina } & Sebelum pengangkutan & $40,1 \pm 0,85$ & $39,3 \pm 0,70$ & $39,8 \pm 0,38$ & $39,7 \pm 0,40$ & \\
\hline & & Sesudah pengangkutan & $41,2 \pm 0,72$ & $39,2 \pm 1,22$ & $41,7 \pm 0,51$ & $40,7 \pm 1,32$ & \\
\hline & & Selisih suhu & $1,06 \pm 0,19$ & $-0,1 \pm 0,60$ & $1,88 \pm 0,61$ & $0,95 \pm 0,99$ & \\
\hline \multirow[t]{6}{*}{ Keranjang konvensional } & \multirow[t]{3}{*}{ Jantan } & Sebelum pengangkutan & $40,3 \pm 0,54$ & $37,5 \pm 0,99$ & $40,9 \pm 0,80$ & $39,6 \pm 1,81$ & \multirow{6}{*}{$1,73 \pm 0,57 \mathrm{a}$} \\
\hline & & Sesudah pengangkutan & $42,6 \pm 0,35$ & $39,7 \pm 1,53$ & $42,7 \pm 0,66$ & $41,7 \pm 1,70$ & \\
\hline & & Selisih suhu & $2,38 \pm 0,88$ & $2,26 \pm 1,48$ & $1,76 \pm 0,15$ & $2,13 \pm 0,33$ & \\
\hline & \multirow[t]{3}{*}{ Betina } & Sebelum pengangkutan & $40,9 \pm 0,50$ & $38,0 \pm 0,29$ & $41,0 \pm 1,14$ & $40,0 \pm 1,70$ & \\
\hline & & Sesudah pengangkutan & $42,4 \pm 0,99$ & $39,5 \pm 0,66$ & $42,0 \pm 0,83$ & $41,3 \pm 1,57$ & \\
\hline & & Selisih suhu & $1,50 \pm 1,14$ & $1,50 \pm 0,91$ & $1,00 \pm 0,39$ & $1,33 \pm 0,29$ & \\
\hline Rataan & & & $1,60 \pm 0,56$ & $1,32 \pm 1,00$ & $1,56 \pm 0,39$ & & \\
\hline
\end{tabular}

Keterangan: angka-angka pada baris yang sama dengan hurus yang berbeda adalah berbeda nyata $(\mathrm{P}<0,05)$; selisih suhu menunjukan perbedaan suhu sebelum pengangkutan dengan setelah pengangkutan; tanda minus (-) mempresentasikan penurunan rataan suhu.

Tabel 6 Perbandingan peningkatan suhu jegger, suhu shank dan suhu rektal

\begin{tabular}{|c|c|c|c|c|c|c|}
\hline \multirow[t]{2}{*}{ Jenis alat } & \multirow{2}{*}{$\begin{array}{c}\text { Jenis } \\
\text { kelamin }\end{array}$} & \multirow[t]{2}{*}{ Bagian tubuh } & \multicolumn{3}{|c|}{ Umur (hari) } & \multirow[t]{2}{*}{ Rataan } \\
\hline & & & 30 & 35 & 40 & \\
\hline \multirow[t]{6}{*}{ M-CLOVE } & Jantan & Jengger & $0,86 \pm 0,43$ & $0,34 \pm 0,50$ & $0,94 \pm 0,55$ & $0,71 \pm 0,33$ \\
\hline & & Shank & $1,40 \pm 1,37$ & $2,30 \pm 1,47$ & $1,28 \pm 0,83$ & $1,66 \pm 0,56$ \\
\hline & & Rektal & $1,44 \pm 0,21$ & $1,60 \pm 0,40$ & $1,60 \pm 0,37$ & $1,55 \pm 0,09$ \\
\hline & Betina & Jengger & $0,90 \pm 0,25$ & $0,54 \pm 1,88$ & $0,44 \pm 0,54$ & $0,63 \pm 0,24$ \\
\hline & & Shank & $1,32 \pm 1,53$ & $1,76 \pm 1,57$ & $1,06 \pm 0,44$ & $1,38 \pm 0,35$ \\
\hline & & Rektal & $1,06 \pm 0,19$ & $-0,1 \pm 0,60$ & $1,88 \pm 0,61$ & $0,95 \pm 0,99$ \\
\hline \multirow[t]{6}{*}{ Keranjang konvensional } & Jantan & Jengger & $2,92 \pm 0,79$ & $3,08 \pm 2,48$ & $1,60 \pm 0,81$ & $2,53 \pm 0,81$ \\
\hline & & Shank & $1,72 \pm 1,34$ & $3,68 \pm 1,79$ & $2,18 \pm 0,31$ & $2,53 \pm 1,02$ \\
\hline & & Rektal & $2,38 \pm 0,88$ & $2,26 \pm 1,48$ & $1,76 \pm 0,15$ & $2,13 \pm 0,33$ \\
\hline & Betina & Jengger & $1,96 \pm 1,93$ & $1,62 \pm 1,98$ & $0,74 \pm 0,09$ & $1,44 \pm 0,63$ \\
\hline & & Shank & $1,96 \pm 1,21$ & $4,88 \pm 1,17$ & $2,56 \pm 0,54$ & $3,13 \pm 1,54$ \\
\hline & & Rektal & $1,50 \pm 1,14$ & $1,50 \pm 0,91$ & $1,00 \pm 0,39$ & $1,33 \pm 0,29$ \\
\hline
\end{tabular}

Keterangan: tanda minus (-) mempresentasikan penurunan rataan suhu.

relatif rendah, panas didisipasi melalui sensible heat loss (SHL) secara radiasi, konduksi, dan konveksi. Mekanisme radiasi panas dari ayam ke lingkungan terjadi akibat perbedaan temperatur permukaan tubuh dan temperatur udara sekitarnya. Konveksi terjadi melalui aliran udara dari jengger, pial, wajah, kaki, jari-jari, leher, tubuh, dan sayap (Yahav et al. 2004). Suhu rektal digunakan sebagai ukuran suhu tubuh karena suhu rektal merupakan pengukur suhu tubuh ayam yang akurat (Yayu dan Dahono 2013).

Peningkatan suhu tubuh yang terjadi pada ayam yang diangkut menggunakan keranjang konvensional lebih tinggi daripada ayam yang diangkut menggunakan M-CLOVE seperti disajikan pada (Tabel 6). Peningkatan suhu tubuh yang lebih tinggi dapat diartikan bahwa ayam berada pada kondisi cekaman panas yang lebih ekstrim pada alat angkut keranjang konvensional. M-CLOVE merupakan desain alat angkut tertutup yang dapat melindungi ayam terpapar sinar matahari langsung. Selain itu, terdapat sistem pengaturan suhu melalui kipas dan ventiasi udara yang menjaga suhu di dalam alat angkut relatif lebih konstan. Perubahan suhu yang tidak ekstrim dapat mengurangi cekaman panas yang dialami oleh ayam broiler (Yayu dan Dahono 2013).

Semakin tinggi peningkatan suhu rektal maka peningkatan suhu jengger dan shank juga semakin tinggi. Hal tersebut sesuai dengan pernyataan Mutaf et al. (2008) bahwa ternak akan mempertahankan suhu tubuh agar tetap berada pada kondisi normal melalui mekanisme rangsangan saraf symphatetik untuk mengeluarkan panas tubuh berlebih. Peningkatan suhu yang terukur dari jengger dan shank ayam broiler lebih besar terjadi pada bagian shank. Peningkatan suhu shank yang lebih tinggi dibandingkan dengan suhu jengger terjadi pada kedua jenis alat angkut M-CLOVE dengan keranjang konvensional dan jenis kelamin jantan 
maupun betina. Hal tersebut disebabkan pelepasan panas pada ayam diarahkan menuju organ-organ yang memiliki pembuluh darah kapiler yang banyak (seperti shank) yang akan efektif mengevaporasikan panas lebih tinggi, dengan meningkatkan laju alir dan volume darah ke organ-organ tersebut (Shinder et al. 2007).

\section{KESIMPULAN}

Pengangkutan menggunakan M-CLOVE dapat mengurangi tingkat stres ayam broiler dilihat dari suhu jengger, shank, dan rektal yang lebih rendah dibandingkan dengan ayam broiler yang diangkut menggunakan keranjang konvensional. Pelepasan panas lebih tinggi pada bagian shank dibandingkan pada bagian jengger ayam broiler.

\section{Saran}

Penelitian lebih lanjut mengenai pengangkutan menggunakan M-CLOVE perlu dilanjutkan dengan menggunakan skala yang lebih sesuai dengan kapasitas angkut ayam yang didasarkan dengan kondisi di peternakan.

\section{DAFTAR PUSTAKA}

Aviagen. 2012. Panduan pemeliharaan ayam broiler strain Lohmann. [Internet]. [diunduh 2015 Jul 4]. Tersedia pada: http://en.aviagen.com/assets/Tech Center/LIR_ Broiler/IRBroilerPerfObj2012R1.pdf.

[BPS] Badan Pusat Statistik. 2014. Statistik Peternakan dan Kesehatan Hewan 2014. Jakarta (ID): CV. Karya Cemerlang.

Dawson WR, Whittow GC. 2000. Regulation of Body Temperature. New York(US): Sturkie's Avian Physiology. G. C. Whittow, ed. Academic Press. Diding L, Andi M. 2011. Regulasi panas tubuh ayam ras petelur fase grower dan layer. Jurnal Sain Peternakan Indonesia 6:2.

Filho FDE, Campos DMB, Torres KAA, Vieira BS, Rosa PS, Vaz AM, Macari M, Furlan RL. 2007. Protein levels for heatexposed broilers: performance, nutrients digestibility, and energy and protein metabolism. Int. Jour. Poult Sci. 7: 711-719.

Kartasudjana R. 2005. Manajemen Ternak Unggas. Bandung (ID): Fakultas Peternakan. Universitas Padjajaran Press.

[Kementan] Kementerian Pertanian. 2014. Konsumsi rata-rata per kapita setahun beberapa bahan makanan di Indonesia, 2009-2013. [Internet]. [diunduh 2015 Feb 4]. Tersedia pada: http://www.pertanian.go.id/ Indikator/tabe-15b-konsumsi-rata.pdf.

Kusnadi E. 2006. Pengaruh temperatur kandang terhadap konsumsi ransum dan komponen darah ayam broiler. J. Pengembangan Peternakan Tropis 33(3): 197 - 202.

Medion. "Merencanakan Pembangunan Kandang dan Peralatannya". 13 Oktober 2015.https://info.medion. co.id/index.php/component/content/article/1 tatalaksana/1377

Mitchell MA, Kettlewell PJ. 1998. Physiological stress and welfare of broiler chickens in transit: solutions not problems. Poult Sci. 77(12):1803-1814.
Mujahid A, Akiba Y, Toyomizu M. 2007. Acute heat stress induces oxidative stress and decreases adaptation in young white leghorn cockerels by downregulation of avian uncoupling protein. Poult Sci. 86: 364-371.

Mutaf SN, Seber K, Firat MZ. 2008. Surface wetting and its effect on body and surface temperatures of domestic laying hens at different thermal conditions. Poult Sci. 87:2441-2450.

Olivo R, Soares AL, Ida EI, Shimokomaki M. 2001. Dietary vitamin E inhibits poultry PSE and improves meat function properties. Journal of Food Biochemistry, Trumbull 25(4): 271-283.

Padli IN, Fajri AI, Kiswanto SH, Salsabila SS, Fatikhunnada A. 2014. Greepbox (green poultry box) rancang bangun sarana transportasi ayam ramah lingkungan sebagai realisasi program operasional transportasi ayam sehat (otas) berbasis Animal welfare. Pekan Kreativitas Mahasiswa. Bogor (ID).

Rahardja DP. 2010. Fisiologi Lingkungan. Makassar (ID): Universitas Hasanuddin.

Shinder D, Rusal M, Tanny J, Shinder D, Yahav S. 2007. Thermoregulatory responses of chicks (Gallus domesticus) to low ambient temperatures at an early age. Poult Sci. 86: 2200-2209.

Suharti S. 2004. Kajian antibakteri temulawak, jahe dan bawang putih terhadap bakteri Salmonella typhymurium serta pengaruh bawang putih terhadap performans dan respon imun ayam pedaging. (Tesis). Bogor (ID): Program Pascasarjana, Institut Pertanian Bogor.

Walpole RE. 1993. Pengantar Statistika (Edisi ke-3). Jakarta (ID): Gramedia Pustaka Utama.

Yahav S, Straschnow A, Luger D, Shinder D, Tanny J, Cohen S. 2004 Ventilation, sensible heat loss, broiler energy, and water balance under harsh environmental conditions. Poult Sci. 83:253-2.

Yayu Z, Dahono. 2013. Respon fisiologis dan evaluasi karkas ayam broiler terhadap suhu pemeliharaan dingin. Seminar Nasional Teknologi Peternakan dan Veteriner. Riau (ID): Balai Pengkajian Teknologi Pertanian Riau.

Yousef MK. 1984. Stress Physiology in Livestock. Florida (US): Basic Principles. CRC Press, Inc. Boca Raton. 